\title{
P014: Acinetobacter is the most common pathogen associated with late-onset and recurrent ventilator-associated pneumonia in an adult ICU in Saudi Arabia
}

\author{
$\mathrm{HH}$ Balkhy ${ }^{1 *}$, A El-Saed ${ }^{2}, \mathrm{HM} \mathrm{Al-Dorzi}{ }^{3}, \mathrm{R} \mathrm{Khan}{ }^{3}, \mathrm{AH}$ Rishu $^{3}, \mathrm{YM} \mathrm{Arabi}^{3}$ \\ From 2nd International Conference on Prevention and Infection Control (ICPIC 2013) \\ Geneva, Switzerland. 25-28 June 2013
}

\section{Introduction}

The guidelines for initial empiric antimicrobial therapy for ventilator-associated pneumonia (VAP) are highly dependent on the type of causative pathogen and the time of diagnosis.

\section{Objectives}

The objective was to examine the microbial causes of VAP and describe any variability by the timing of VAP onset and over-time.

\section{Methods}

The current study was a prospective surveillance conducted at adult general ICU of a tertiary care hospital at Riyadh, Saudi Arabia. Microbial isolates obtained from blood and different respiratory specimens of patients diagnosed with VAP (using CDC definition) between August 2003 and June 2009 were included.

\section{Results}

A total of 457 pathogens were identified during the study; $380(83.2 \%)$ were associated with primary VAP and 77 (16.8\%) were associated with recurrent VAP. Of primary VAP pathogens, $159(41.8 \%)$ were associated with early-onset ( $<5$ days) and $221(58.2 \%)$ were associated with late-onset ( $\geq 5$ days) VAP. The most common pathogens identified were Acinetobacterspp. (26.5\%) followed by Pseudomonas aeruginosa (21.7\%),

'Infection Prevention and Control Department, King Abdulaziz Medical City, Riyadh, Saudi Arabia

Full list of author information is available at the end of the article
Staphylococcus aureus including MRSA (15.3\%), Klebsiella spp. (6.8\%), Haemophilus spp. (6.1\%), and Enterobacter spp. (5.0\%). Acinetobacterspp. and MRSA were significantly associated with late-onset VAP while Haemophilus spp. and Streptococcus pneumoniae were significantly associated with early-onset VAP. Acinetobacter spp. was the only pathogen associated with recurrent VAP and its incidence showed a significant increasing trend during the study period. Acinetobacter spp. was significantly associated with prolonged ventilation, sedation, and nasogastric intubation.

\section{Conclusion}

Acinetobacter baumanii is the most common and increasingly important pathogen associated with VAP in our patients, especially late-onset and recurrent VAP. Our ICU should continue actively screening for Acinetobacter in all admitted patients, shorten ventilation duration, minimize sedation, encourage oral gastric rather than nasogastric intubation, and improve currently implemented infection control measures including environmental disinfection.

\section{Disclosure of interest}

None declared.

\section{Author details}

${ }^{1}$ Infection Prevention and Control Department, King Abdulaziz Medical City, Riyadh, Saudi Arabia. '2Department of Infection Prevention and Control, King Abdulaziz Medical City, Riyadh, Saudi Arabia. ${ }^{3}$ Intensive Care Department, King Abdulaziz Medical City, Riyadh, Saudi Arabia.

\section{C)

C 2013 Balkhy et al; licensee BioMed Central Ltd. This is an Open Access article distributed under the terms of the Creative Commons Attribution License (http://creativecommons.org/licenses/by/2.0), which permits unrestricted use, distribution, and reproduction in any medium, provided the original work is properly cited. 
Published: 20 June 2013

doi:10.1186/2047-2994-2-S1-P14

Cite this article as: Balkhy et al:: P014: Acinetobacter is the most

common pathogen associated with late-onset and recurrent ventilator-

associated pneumonia in an adult ICU in Saudi Arabia. Antimicrobial

Resistance and Infection Control 2013 2(Suppl 1):P14.

Submit your next manuscript to BioMed Central and take full advantage of:

- Convenient online submission

- Thorough peer review

- No space constraints or color figure charges

- Immediate publication on acceptance

- Inclusion in PubMed, CAS, Scopus and Google Scholar

- Research which is freely available for redistribution

Submit your manuscript at 